\title{
Convergence and cohesion: the contribution made by Poland to the debate about regional policies of the European Union
}

\author{
Simona Epasto \\ University of Macerata Department of Political Science, Communication and International Relations \\ Strambi Plaza 1, 62100 Macerata: Italy \\ simona.epasto@unimc.it
}

\begin{abstract}
The importance of Poland to the European Union is first and foremost an excellent example of the success of the EU enlargement: a Country in which the benefits of the membership had the effect of dampening the euroscepticism and brought stability both on an economic and a political level. At the same time the significant contribution that Poland has brought to the management of difficulties due to the economic crisis is undeniable, not only because its economic structures are facing the global economic downturn in an excellent manner, but mainly because, even in this context, it supports the need for greater cohesion between the various partners. Poland seems to demonstrate a strong European feeling as well as the fact that it defends the way of a combined support to Member States at risk of bankruptcy and it's making out of itself a promoter of an approach based on solidarity. The aim of this paper is to explore the Poland's case on many levels, from the debate concerning the potential of cohesion policy to the need of finding the necessity of reinforcing the economic governance of the EU as a whole, new solutions for helping the economies of the European periphery, from the question about a real politic multilevel union to the actual geoeconomics and geopolitical dynamics between the EU and its eastern countries politics. It could be used as an example to the virtuous use of structural funds of the EU and to consider a new approach to reduce regional disparities that takes into consideration local peculiarities. It also could represent an important starting point in order to pave the way to new policies and outlining strategies in the search for real convergence.
\end{abstract}

Keywords: cohesion policy, Europe 2020 Strategy, Poland, European Union, regional policies, convergence, regional growth and development, multilevel governance.

\section{Introduction}

There are numerous policies, grouped under the general name of "Cohesion Policy", which were conceived as a partial counterweight to the "natural" effects of the internal market, promoting a more balanced distribution of resources and a more harmonious development of all EU countries. The increasing importance given to these policies reflects the awareness that a vigorous cohesion policy is essential for reasons of social justice. In particular, the regional policies are conceived to support the investments in regions that are lagging behind in development, the number of which has greatly increased after successive enlargements in 2004. The early interventions to rebalance the regional development took place in regions lagging behind in development by investing in infrastructure or directly in supporting the productive activities. In this way it is thought to enhance the public capital 
of the less-equipped regions to pursue the objectives of territorial equity and reduce inter-regional imbalances. From the European perspective, the problem becomes even more obvious and it exceeds some possible cultural specificities. The first question is whether regional policies are effective in helping to create territorial assets, defined as local public goods whose accessibility depends also on the territorial proximity; regional policies can have a Keynesian effect of a short-term, while greater importance is pertained to investing in assets capable of supporting a territorialized development of a long-term. The production of local goods, understood as an investment in the territorial potentialities, becomes a pre-condition for a development that is sustainable in the long run, as it is able to regenerate the assets used. In particular, it is necessary to check whether the differential investment in territorial assets determine a development gap with other regions. Finally, this analysis is carried out considering different types and locations of regions.

The EU regional policy supports the reduction of the structural differences between the regions, the balanced development of the European territory, as well as the promotion of effective equality of opportunity between people. Based on the concepts of solidarity and economic and social cohesion, this policy is executed through a variety of financing, in particular those of the Structural Funds and the Cohesion Fund. The Cohesion Policy 2014-2020 represents approximately one third of the EU budget, thus affirming its role as the main Community instrument for growth, creation of jobs and the implementation of EU policies.

The importance of Poland to the European Union is first and foremost an excellent example of the success of the EU enlargement: a Country in which the benefits of the membership had the effect of dampening the euroscepticism and brought stability both on an economic and a political level. At the same time the significant contribution that Poland has brought to the management of difficulties due to the economic crisis is undeniable, not only because its economic structures are facing the global economic downturn in an excellent manner, but mainly because, even in this context, it supports the need for greater cohesion between the various partners. Poland seems to demonstrate a strong European feeling as well as the fact that it defends the way of a combined support to Member States at risk of bankruptcy and it's making out of itself a promoter of an approach based on solidarity.

Poland's case is interesting on many levels, from the debate concerning the potential of cohesion policy to the need of finding the necessity of reinforcing the economic governance of the EU as a whole, new solutions for helping the economies of the European periphery, from the question about a real politic multilevel union to the actual geoeconomics and geopolitical dynamics between the EU and its eastern countries. Through the analysis of Poland's case, it's highlighted that Polish politics could be used as an example to the virtuous use of structural funds of the EU, and it considers a new approach to reduce regional disparities that takes into consideration local peculiarities. It could represent an important starting point in order to pave the way to new policies and outlining strategies in the search for real convergence based on the territorial potentialities and on the multilevel governance.

\section{Cohesion policy 2014-2020 and the Europe 2020 strategy: promoting the potential innovation of the regions}

The allocation of funds from the Cohesion Policy in favour of the Member States for the period 20142020 reflects the state of the negotiations in July 2013. The Cohesion Policy 2014-2020 represents 
approximately one third of the EU budget, thus affirming its role as the main Community instrument for growth, creation of jobs and the implementation of EU policies. The Commission worked with national and local authorities to identify investment priorities of each country for the new funding period and it is committed to ensuring that the funds have a major impact on the competitiveness and creating jobs, while continuing to focus on the main issues and the results of policy reform. The legislative proposals for Cohesion Policy in 2014-2020 were adopted by the European Commission on 6 October 2011.

As a consequence of the proposals and in order to help the Member States to prepare for the next programming period the Commission presented the "Common Strategic Framework" (CSF) (European Commission 2012a; European Commission 2012b). The goal is to favour the setting of the strategic direction for the next period of financial planning that goes from 2014 to 2020 in the Member States and in the relevant regions. This will allow getting a better combination of the various funds in order to maximize the impact of EU investment. The national and regional authorities will use this strategic framework as a basis for drawing up the "Contracts of partnership" with the Commission and shall endeavour to achieve the objectives of growth and jobs in Europe by 2020.

Participation of the regions is crucial to achieving the objectives of the Europe 2020 strategy. The Commission then assesses the ways in which regional policy can contribute to the growth of the innovation potential of the European Union. It therefore presents the practices that can be used by the regions to foster innovation, waiting for the objectives of the next Structural Funds programming.

The Europe 2020 strategy aims to raise the economy of the EU over the next decade (European Commission 2010b). In a changing world, the EU aims to become a smart, sustainable and an inclusive economy. These three priorities mutually reinforcing each other intend to help the EU and the Member States achieve high levels of employment, productivity and social cohesion.

Actually, the Union has set five ambitious objectives - employment, innovation, education, social inclusion and climate/energy - to be reached by 2020. For each of these areas each Member State has adopted its national targets. Concrete actions at the EU and national level should consolidate the strategy.

The Commission proposes a new political strategy "Europe 2020" in support of employment, productivity and social cohesion in Europe. Today, the EU is actually experiencing a phase of transformation, especially due to globalization, climate change and aging population. In addition, the 2008 financial crisis has called into question the social and economic progress made by the EU countries. The economic recovery commenced in 2010 must, therefore, be accompanied by a series of reforms to ensure sustainable development of the EU in the next decade.

All EU Member States have committed themselves to implement the Europe 2020 strategy. However, each country has different economic situation and this translates the general objectives of the EU into its own objectives in the National Reform Programme, a document that presents the policies and measures planned by the country to support growth and jobs in line with the strategy Europe 2020; it is presented simultaneously with the stability or convergence program which defines the budget plans for the next three or four years. A thematic synthesis has been elaborated in order to facilitate the comparison of the Member States and to locate the economic challenges they face in a wider context. The synthesis involves the main political issues of the Europe 2020 strategy. For each topic a set of core indicators was selected to be able to compare the different positions of the Member States. The summaries also contain general guidelines on policies to remedy the detected 
deficiencies and accelerate the achievement of the objectives that have already been set. The thematic synthesis complete the most detailed national analyses contained in the work documents of the Commission, which also determine the recommendation proposals that are to be addressed to the individual countries. It should be emphasized that these recommendations are based on a thorough examination of the issues that each Member State is called upon to deal with, taking in consideration all the relevant factors and, therefore, a more complete picture than the one drawn by the core indicators included in the synthesis of the themes listed below.

European regional policy can make a substantial contribution to the objectives of the Europe 2020 strategy, in particular under the Innovation Union flagship initiative. In fact, the regional policy and its funding may be used for research and development, education, entrepreneurship and technologies of information and communication.

The regions of Europe have different levels of development and different potential for innovation. The public interventions must, therefore, be adapted to the diversity of these situations. Therefore, regional policy supports at the same time the performance of the most advanced regions and the reorientation of regions lagging behind regarding the more competitive activity. The regional policy funds are coordinated through the Competitiveness and Innovation Framework Programme (CIP) and the 7th framework program for research and development.

To achieve the objectives of the Europe 2020 strategy (European Commission 2010a), the regional policy should particularly allow for: strengthening of the competitiveness of a region by deploying resources in activities with high added value, supporting skills, education and infrastructure; developing smart specialization strategies in combination with other EU policies; promoting particular market sectors; developing governance at various levels; creating links between policy areas and between regions.

In addition, the regional policy encourages cooperation of companies, research centres and universities in order to define the specialization strategies that would be appropriate to their regional context and investment capacity. Such specialization strategies should encourage: creation of groupings of companies or "clusters" based on innovation to share services and infrastructure; conditions for innovation of SMEs which will play a major role in the growth, employment, innovation and cohesion of the EU; the lifelong learning programs in research and innovation in partnership with universities and local businesses; regional research infrastructure, including creation of infrastructure networks in the weaker regions and use of the technologies of information and communication; the creative and cultural industries; digital strategies based on faster Internet applications; the use of public procurement financed by the European Regional Development Fund (ERDF) to accelerate the commercialization of innovations; partnerships for innovation of the Europe 2020 strategy.

It is necessary to establish synergies between Community policies in support of research and innovation. To this end, the Commission should simplify and harmonize standards for the use of programs designed to promote cooperation among innovation actors. This also requires the synergies and groupings among regional actors of innovation. In this context, regional policy supports the development of programs, transnational and interregional cooperation. It also sustains, in particular, the creation of science and technology parks or incubators.

After 2013, innovation, research and development should be top priorities of cohesion policy and the EU budget. However, during the current programming period of the Structural Funds, EU Member States and their regions should already redirect their practices to increase their innovation potential. 


\section{Case of study: Poland}

\section{The Polish Presidency of the EU: priorities, objectives and results}

The first Polish Presidency of the EU in July 2011 has certainly been a historic moment and an opportunity for Poland to build the foundations for a more influential role at the international level. At the same time, the situation of Poland can give new life in Brussels, Poland being a young country that is stable and going through a rapid development.

The ambition of the Polish Presidency, as set forth by Prime Minister Tusk was to be able to restore confidence in the European Union and the necessity of its existence, reinforcing the sense of belonging of the Member States and rediscovering the core values of the integration (Tusk 2011). The program developed for the II semester of 2011 has actually been opened with the prediction of actions aimed at strengthening cohesion among the Member States through the development of strategies agreed in the name of a common European interest. In this sense, it was fundamental to Warsaw to spread a conception of European integration as "a source of growth" and pursuing this objective both in terms of economic growth and of a deepening of cooperation among the States. The country has in fact strongly supported the proposals of an act for the single market in order to facilitate free circulation, development of cross-border digital services and online trade. At the same time, monitoring the stability of public finances was also fundamental through the verification of European countries compliance with the agreed objectives for the budget in the first half of the year.

During the Polish Presidency, the European States have also begun negotiations on the proposals relating to the budget for the 2014-2020 period; in this context, Poland has urged European leaders to focus on growth funds with investment in infrastructure and training. In the Polish program plenty of space has also been devoted to proposals for better regulation of the financial markets in order to avoid further crisises. In fact Poland took over the rotating presidency of the EU in a very sensitive moment characterized by an uneven economic recovery, the debt crisis of Greece and the instability in North Africa following the Arab Spring. Additional priorities have been represented by the need to develop a common approach in the field of food and energy supplies, security and defence. At the international level, relations were intensified between the EU and many countries of Eastern Europe, such as Armenia, Azerbaijan, Georgia, Moldova, Ukraine and Belarus, in order to carry on negotiations on association agreements to remove trade barriers and liberalize visas. The Polish program also provides for a common approach to encourage North African countries to move to democracy.

As amply demonstrated in the following years, the lack of a shared political will which operates in the direction of growth so dually understood, is equivalent, in fact, a source of weakness, able to put at risk not only the image of the European Union as an entity precisely "united", but also its future. The determination, realism and clear ideas that Poland has shown and still shows to have on these points, combined with the European enthusiasm shown by Warsaw, are the hope for a change of course that would animate the whole union. An example of this is the fact that, according to the presented schedule, Warsaw is determined to make its voice heard even on the issue of free movement of persons, founding pillar of the European Union, recently put into question by Denmark's decision to suspend the Schengen Treaty, restoring customs controls at the borders. As evidence of the Polish effort in favour of greater cohesion within the European Union, Prime Minister Tusk commented the news and reaffirmed the determination of Poland as the Presidency to oppose initiatives that, such as the one of Copenhagen, consist in stepping back to Brussels. 
Such a view is based on the belief that the European Union needs to avoid relegation on the road to integration, to expand its fields of competence and, therefore, to revive those policies on which there is no consensus. In this respect, one of the main challenges that Poland has faced and continues to face is the need for a real convergence in foreign policy and defence, i.e. the areas in which sharing of views is missing, also as harmonization of initiatives, despite the provisions of the Treaty of Lisbon. This lack of convergence has come to light, in its most extreme criticality, on the occasion of the Arab Spring, in which the EU has been unable to speak with one voice and the individual states have rather preferred to decide for themselves. The priority given to these issues is explained by recalling the history, the geographical location and the geopolitical value of this country: situated between Germany and Russia, Poland has experienced three divisions, subdued for much of its history to foreign domination, forced to follow cultural patterns and development imposed from outside, and then, finally, reconstituted the coveted national unity (Zamoyski 1994; Lukowski \& Zawadzki 2009). The signs of this past are indelible; never-dormant fears of Poland regarding any interference on the part of Moscow, for example, are still at the origin of the Warsaw efforts aimed at the establishment of a European defence policy, which would represent a guarantee of a greater safety for this country. After all, that this topic is dear to Poland is confirmed by the fact that Warsaw is moving, in order to ensure the defence of the country, in more than one direction, particularly to the United States, and at the same time to Europe. Poland also aims at creating a tactical-military command with the countries of the Visegrad Group, an alliance between Poland, Czech Republic, Slovak Republic and Hungary signed in 1991, in view of the a joint accession of these countries to the European Union. Projects like this that promote greater cooperation between the Member States, although geographically limited, represent important steps towards the creation of security in the European mould which the EU might enhance, even in consideration to the influence which, by its very same nature, Poland could exercise in this area. The support for these initiatives would also leave less space to agreements involving countries from outside the EU and therefore able to divert the interests of the Member States towards a dimension of security that is not of European nature.

The concerns of Poland also relate to energy security, also linked to the desire to break free from Moscow and to make the European Union energetically independent from Russia through the common choices to diversify the source of supply and ensure reliability in the international markets. In this regard, it is worth mentioning only the project of exploitation of shale gas, a type of natural gas that some experts consider the new frontier in the field of energy and which is present in large amounts on Polish territory. If it can overcome the resistance of the environmental movement, alarmed at the risk of pollution of groundwater and of air resulting from the extraction, Poland can really hope for energy independence that will have a significant impact on the national and European economy. According to the experts shale gas could meet much of our energy needs. But the procedure of extraction, i.e. fracking, continues to spark protests especially in Britain and Eastern Europe. Based on the estimates, Poland, Romania, France, Ukraine and UK have large quantities of shale gas which, extracted, could give impetus to the European energy sector. For these reasons, for years governments and energy majors have been cooperating. The first gives licenses, the latter explores and evaluates whether and to what extent to proceed with fracking or hydraulic fracturing, is the system by which water, mixed with chemicals, is pumped at high pressure in the underground to extract the shale gas. In Poland, where, however, there are controversies about the real correspondence between the very high estimates and the actual amount of shale gas, have so far been granted hundreds of licenses. But it was in Ukraine that the two most important sector contracts were signed, which are worth about ten billion Euros each. 
The demonstrations against the extraction of gas, now widespread in Eastern Europe, seem to re-evaluate that part of the continent certainly not famous for its ecological sensitivity. On October 19, 2013, the day on which the Global Frackdown was held, coordinated global initiative, also in Lviv, the largest city in western Ukraine, demonstrations were held against Chevron, the company that has just obtained a license. Even in Poland, in Gdansk, Warsaw and Żurawlów there were demonstrations linked to the Global Frackdown. Particularly at Żurawlów, village in the southeast of the country at the border with Ukraine, the poorest area of Poland, Chevron wants to fracture the rock and pull out shale gas. Initially, reading the news, the locals were in favour of the project. Then the environmental groups have begun to explain the potential collateral damage and the public has embraced the ecologist cause (Tacconi 2013).

On the 17th April 2012, the Council of Ministers adopted the final report of the Polish Presidency of the European Union Council. The report illustrated with tables, diagrams and photographs is a joint effort of all departments that were involved in the preparation and execution of the Polish Presidency of the EU Council (Rzeczpospolita Polska Ministerstwo Spraw Zagranicznych 2012).

\section{Lessons of Europeanism, the economic and financial system and the Eurozone}

Poland can make a significant contribution to the European Union also with regard to the management of difficulties due to the economic crisis. Not only, in fact, it can serve as an example for other countries, because its structures are facing the global economic downturn in an excellent manner, but mainly because, even in this context, Warsaw supports the need for greater cohesion between the various partners. As a matter of fact, facing the reluctance of those who pronounce in favour of the return to national economies, Poland defends the way of a joint support to Member States at the risk of bankruptcy and it is promoting an approach based on solidarity. After all, it could not be otherwise, since the word "solidarity" is very closely linked to a country in which the trade union "Solidarność" has played a central role in the revival of national unity and in the history of Europe (Bova 2005). Poland, although it hasn't took part in it yet for the reasons listed below, seems to demonstrate a strong European feeling that does not put into question the benefits of economic and monetary union as those who see the abolition of the Euro as the solution to all their problems. Therefore, a spirit of solidarity, which certainly is not strange to evaluations of the importance that the country represents, the single European market and the need for the economic system of the European Union as a whole would not know any recessions. Poland is, in fact, a young State rapidly growing, potentially influential both because of its demographic dimension, and on the economic scale, also thanks to the integration with Brussels, it has been able to better exploit its own resources, to modernize the system and become more competitive. This is evident especially in the agricultural area, a leading sector in Poland, where subsidies of Brussels and the Community market have enabled rapid development. If, however, because of the presented circumstances, Poland may help to consolidate the sense of belonging of the Member States to the European "family", demonstrating the usefulness of integration, it is also true that Warsaw may not yet have a decisive role on these issues. It is difficult; in fact, that a State which represents $5 \%$ of the GDP of the European Union and especially which is not included in the Euro zone could deal with Community economic issues on par with the most influential nations.

Not to be plagued by the problems of the Euro area, Poland is planning to postpone to a later date the entry into the single currency zone. For the strength of the euro is not to be considered an 
alarm in itself. On the other hand, the news of the turnabout of Warsaw, even if only temporary, is a signal that could worry the governments of European countries where the euro is adopted, because it is an indirect indictment of the monetary and fiscal policy of the EMU.

Looking at the characteristics of Poland, it is better understood why the Polish braking could be read as a serious wake-up call for the EU and the ECB. At the economic level, first of all, the economy of Poland is traveling at rates far higher than those of the other EU countries. In 2008, the year of the collapse of Lehman Brothers, the GDP grew by 5.1\% and in 2009, while the rest of the EU fell into recession, registering a negative growth of GDP $(-4.1 \%$ on average in the countries Euro area), Warsaw had managed to keep bang and grow by $1.7 \%$ despite a series of speculative attacks on its currency, the zloty. According to European Commission estimates the Polish GDP growth, although at a slower pace than in the past, records a more positive performance than in the rest of the euro area: $+4 \%$ in 2011, decline in $2012(+2.5 \%)$ and ascent in $2013(+2.8 \%)$ (Tab. 1) (Fig. 1) (Tab. 2) (Tab. 3) (Tab. 4).

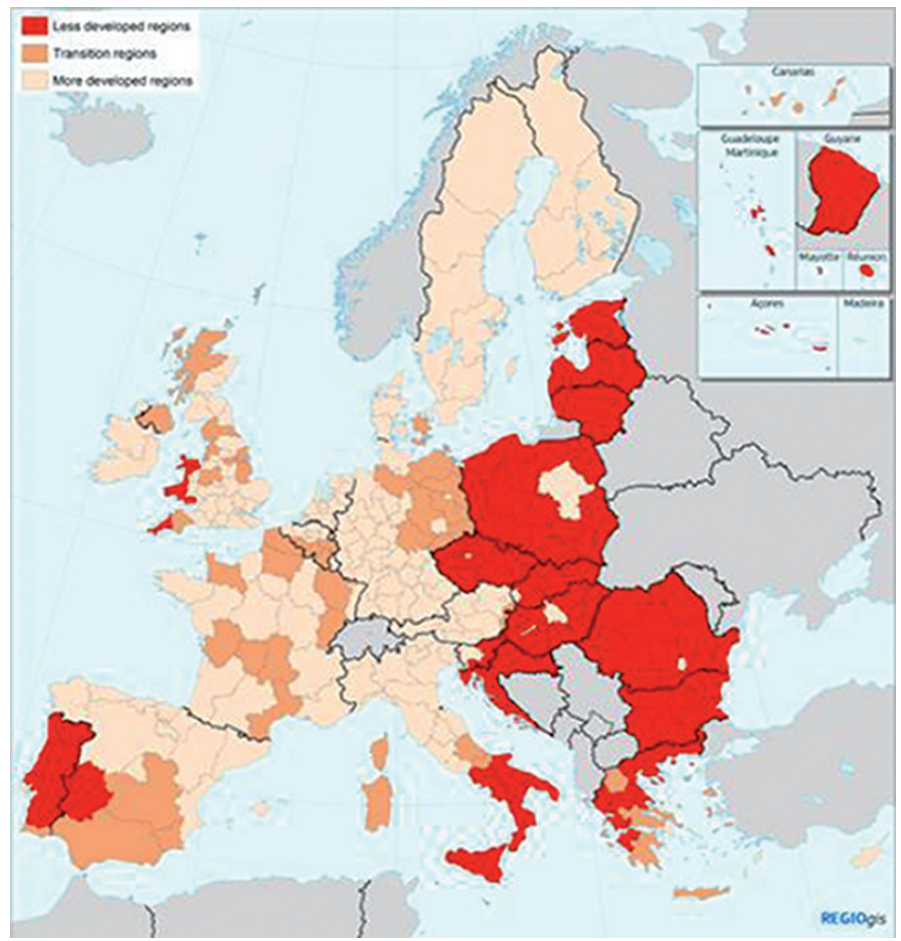

Figure 1. Structural Funds 2014-2020 (ERDF and ESF) Source: http://ec.europa.eu/regional_policy/what/future/eligibility/index_en.cfm. 
Table 1. Income level

\begin{tabular}{|l|l|l|}
\hline Poland \\
\hline Income level & GDP (current US\$) & Population (total) \\
\hline High income: OECD & $\$ 489.8$ billion (2012) & 38.54 million (2012) \\
\hline
\end{tabular}

Source: World Bank.

Table 2. Growth trends 2002-2011

\begin{tabular}{|l|l|r|r|r|r|}
\hline & & $\mathbf{2 0 0 2}$ & $\mathbf{2 0 0 3}$ & \multicolumn{1}{|c|}{$\mathbf{2 0 1 0}$} & $\mathbf{2 0 1 1}$ \\
\hline Poland & GNI per capita, PPP (current international \$) & $11,520.0$ & $11,870.0$ & $19,220.0$ & $20,200.0$ \\
\hline Poland & Population, total (in millions) & 38.2 & 38.2 & 38.2 & 38.5 \\
\hline Poland & GDP (current US\$) (in millions) & $198,179.4$ & $216,800.9$ & $469,736.8$ & $515,666.9$ \\
\hline Poland & GDP growth (annual \%) & 1.4 & 3.9 & 4.1 & 4.5 \\
\hline Poland & Life expectancy at birth total (years) & 74.5 & 74.6 & 76.2 & 76.7 \\
\hline
\end{tabular}

Source: World Bank.

Table 3. Poland: Country Profile - Human Development Indicators

\begin{tabular}{|l|r|r|}
\hline Human Development Index & Ranking & 39 \\
\hline Health & Life expectancy at birth total (years) & 76.3 \\
\hline Education & GNI per capita in PPP term (constant 2005 international \$) & 17,776 \\
\hline Income & (Constant 2005 international \$) & 1.4 \\
\hline Inequality & MPI: Multidimensional poverty index (\%) & n.a. \\
\hline Poverty & GII: Gender Inequality index, value & 0.140 \\
\hline Gender & Carbon dioxide emissions per capita (tonnes) & 8.3 \\
\hline Sustainability & Population, total both sexes (thousands) & $38,317.1$ \\
\hline Demography & Non-income HDI value & 0.851 \\
\hline Composite indices & Fixed and mobile telephone subscribes per 100 people & 143.0 \\
\hline Innovation and technology & (per 100 people) & Income index \\
\hline Trade, economy and income & 0.765 \\
\hline
\end{tabular}

Source: Human Development Report 2013. 
Table 4. Poland: Country profile - Human Development Index

\begin{tabular}{|c|c|c|c|c|}
\hline \multicolumn{4}{|c|}{ Human Develpment Index } & Ranking 39 \\
\hline Year & Poland & Very high human development & Europe and Central Asia & World \\
\hline 2012 & 0.821 & 0.905 & 0.771 & 0.694 \\
\hline 2011 & 0.819 & 0.904 & 0.769 & 0.692 \\
\hline 2010 & 0.817 & 0.902 & 0.766 & 0.690 \\
\hline 2009 & 0.813 & 0.898 & 0.762 & 0.685 \\
\hline 2008 & 0.811 & 0.898 & 0.762 & 0.683 \\
\hline 2007 & 0.806 & 0.896 & 0.757 & 0.678 \\
\hline 2006 & 0.802 & 0.892 & 0.750 & 0.672 \\
\hline 2005 & 0.798 & 0.889 & 0.743 & 0.666 \\
\hline 2000 & 0.778 & 0.867 & 0.709 & 0.639 \\
\hline 1995 & n.a. & n.a. & 0.684 & 0.618 \\
\hline
\end{tabular}

Source: Human Development Report 2013.

From the structural point of view, however, Poland is marked by a brilliant management of monetary and fiscal policy and by a strong role of the central bank, which has built over time a substantial degree of independence from the executive in charge. In 2007, for example, according to international criteria Gmt the rate of autonomy of the Polish Central Bank was 92\%, equal to that of the ECB, and well above the Bank of England, 65\%, and the Fed, 78\%, in the same year. The Polish Central Bank is also demonstrated as independent from the banks because it does not have any supervisory tasks; financial supervision is in fact entrusted to a unique independent authority, the Polish Financial Supervision Authority. This type of structure based on independence and specialization has allowed the Polish central bankers to focus solely on monetary stability while keeping inflation under control (in 2000 the inflation rate was in double digits in 2007 was $1.4 \%$, the monthly data of October 2010, after a period of renewed tension it was $2.6 \%$ compared to the average of $2 \%$ in the Eurozone) and controlling the zloty, as happened recently, in order not to zoom public debt (in 2011 the ratio of debt to GDP was 54\%) and to maintain the competitiveness of the currency in exports. The Central Bank has facilitated, therefore, also the management of economic policy, allowing the government to keep their accounts in order during the crisis (the deficit to GDP, for example, was 3\%). And the good health of the state budget, in turn, has given the opportunity to make an expansionary fiscal policy accompanied, in recent years, even from an expansionary monetary policy, that has stimulated the demand and led to devalue the local currency, without generating, as said, a level of untenable inflation. Fiscal discipline, monetary discipline and financial supervision entrusted to a single independent body; it is for these three reasons that Poland, while wishing for years to come in the euro area, this time waivers to make its entry into the club of the single currency. Now if it comes in the Economic and Monetary Union it would find only one of these three characteristics, i.e. the monetary discipline. As the rest, i.e. fiscal discipline, it is far from a reality in spite of the recent agreements reached by the leaders of the EU countries with the exception of England; the European states are only partially ready to cede sovereignty in this area and the most financially 
solid - Germany in the first place - they are not willing to take on the debts of others through the instruments such as Eurobonds. The last pillar that makes the Polish economy more prosperous than other economies in Europe, the consolidated financial supervision, it is equally absent in the EU because the supervision mechanism is limited to a system of cooperation with decentralized powers that involves three federal agencies (respectively for banks, securities markets and insurance) and leaves to the national authorities the task of surveillance and crisis' management.

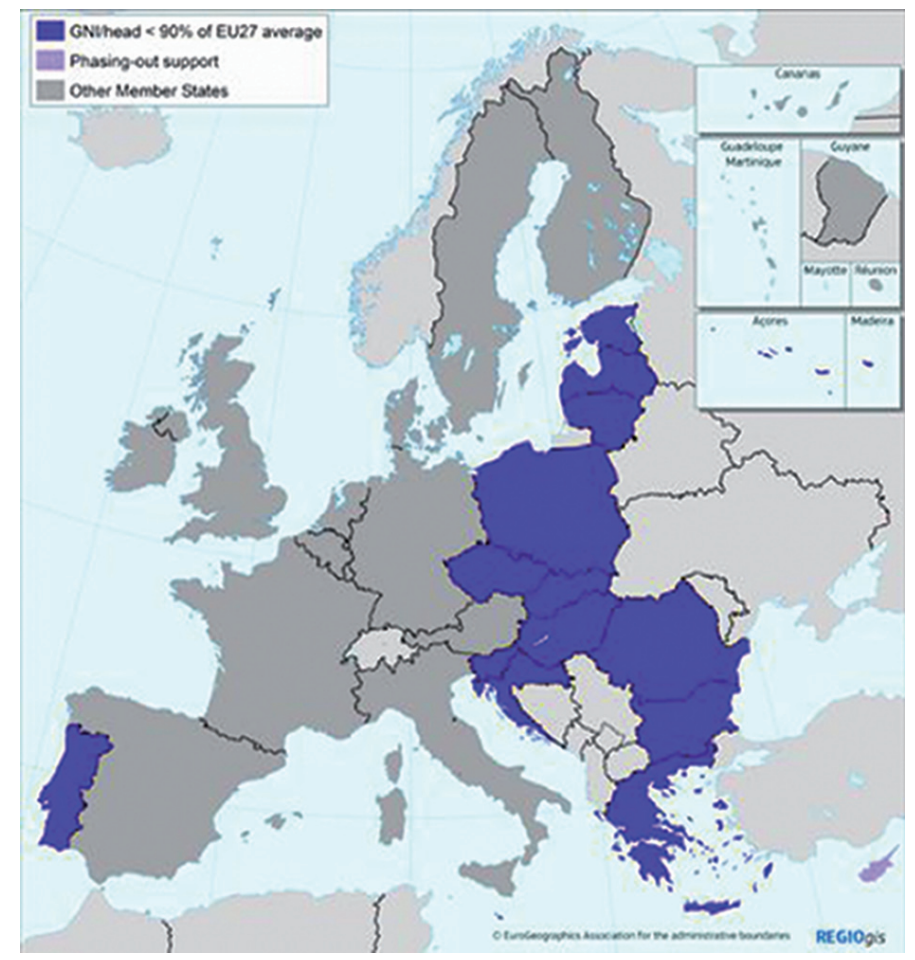

Figure 2. Cohesion Funds 2014-2020

Source: http://ec.europa.eu/regional_policy/what/future/eligibility/index_en.cfm.

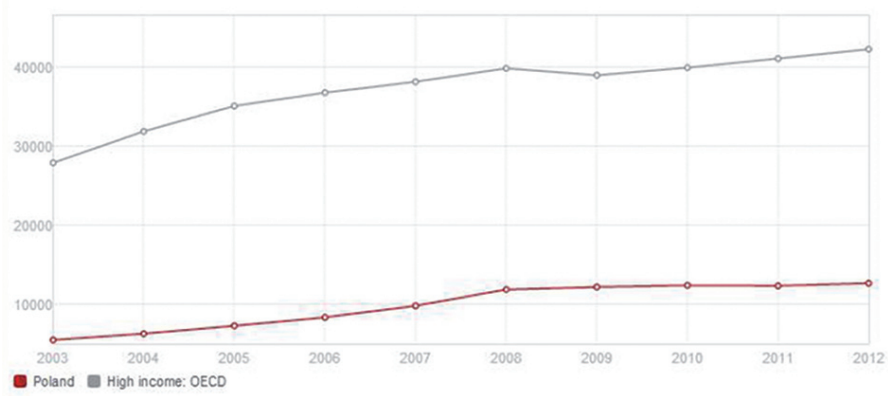

Figure 3. GDP (current US\$)

Source: World Bank. 


\section{Ambiguity of Polish policy: the problem of European Roadmap}

The 2050 European Roadmap for the climate was blocked because of the veto of Poland which is a carbon-dependent economy. During the Environment Council of the European Union of 2011, despite the favourable opinion of the other $26 \mathrm{EU}$ member states and the efforts of the President of the Council, the strategy presented by the European Commission was rejected because of the Polish veto (European Commission 2011). The text is planning to build a sustainable economy by 2050, focusing on energy efficiency and renewable energy sources in all sectors. The ultimate goal is to decrease by 80 to $95 \%$ of $\mathrm{CO}_{2}$ emissions compared to 1990 levels, with some intermediate goals: $-25 \%$ in $2020,-40 \%$ in 2030 and $-60 \%$ in 2040 .

A path that does not look good for Poland; according to Warsaw, the EU should be limited to set a goal to 2050, leaving to the Member States the task of determining the manner and timing of emission reductions.

This is just the latest act in the long history of the Polish obstructionism towards the measures to reduce the emissions of $\mathrm{CO}_{2}$. Poland, in fact, is a country heavily dependent on carbon (about $90 \%$ of the electricity mix). By using this most polluting fossil fuel Poland could not adapt to the objectives of the Roadmap except at great cost, by purchasing on the market the emission credits needed to offset the obsolescence of its thermal power plants.

The European Environment Commissioner has said, however, convinced that Poland will not stop Europe's transition towards an economy at low emissions of $\mathrm{CO}_{2}$. And in fact strides have been made in recent years.

In March 2013 the European Parliament, starting from the Roadmap to 2050 developed by the Commission, highlighted the policies to be adopted for achieving the objectives of European energy policy to 2050, assuming as a starting point the objectives that Europe has posed to itself for 2020 (European Parliament 2013). Among the various directions given to the Commission, the EU Parliament emphasized the need to adopt the strategy of "regional energy specialization" so that the regions could develop energy sources more efficient in achieving the European targets for 2050, such as solar power in the South and wind in the North. The specialization - developing renewable depending on the type of EU country and its region - is essential to contain costs and improve efficiency. In addition, the transition towards an economy of low-carbon emissions and efficient energy represents for the Parliament an opportunity not only for sustainability but also for the security of supply and competitiveness in Europe. The reduction in emissions of greenhouse gases will be a competitive advantage in the global market for products and services related to the energy sector that is growing. Finally, the Parliament highlights, there will not be any discount or compromise on safety both for plants to fossil fuels and to nuclear power plants.

On 21 November, 2013, a meeting with the Climate and Clean Air Coalition (CCAC) was held in Warsaw. Poland, which joined the coalition in February, has presented its achievements in the field of climate protection and air. The most important issues raised during the summit are to promote green transport, cooperation in the reduction of methane emissions associated with the extraction of crude oil and adoption of practical measures to reduce air pollution in the short term. The Coalition has also presented a series of proposals to fight climate change which causes, among other things, the degradation of ecosystems.

The meeting was attended by Beata Jaczewska, State Undersecretary at the Ministry of Environment. The president of the Polish delegation at the summit highlighted that Poland was proud to be a member of the CCAC and showed that there was a need for involvement in the coalition of all the countries of Central and Eastern Europe, in order to exploit the full potential of this region. Poland 
is the first country in Central and Eastern Europe to become a partner of the coalition. During the meeting, Minister Jaczewska also recalled the Polish efforts to improve air quality through a series of national programs. According to the research of the Inspectorate of Environmental Protection air quality, since 2012, the Polish situation is constantly improving (Ministerstwo Środowiska 2013). For example, in February 2013, the Ministry of Environment and the National Fund for Environmental Protection and Water Management have started the program Kawka, with a budget of 800 million. Its purpose is to reduce emissions by increasing energy efficiency and by developing renewable energy sources.

At the Summit, Poland has also highlighted the success of the Green Investment Scheme (GIS), which consisted in the investments in low-carbon energy sources (Ministry of the Environment 2013). One of the examples of GIS projects is the "Gazelle", which refers to a transport at low carbon content. The program is compatible with one of the objectives of the CCAC on reducing emissions from heavy duty vehicles and diesel engines (Narodowy Fundusz Ochrony Środowiska i Gospodarki Wodnej 2013).

\section{A dynamic economic system: international trade, infrastructures and capitals}

The dynamism of the Polish economy, also because of the grip of the crisis, continues to accelerate the run-up towards the average of the gross domestic product of the European Union with a GDP that since 2004 has had a jump of $46.3 \%$, the best performance ever at European level: the analysis is contained in a report by the Polish Foreign Ministry drafted based on the nine years of EU membership. While slowing its growth since 2008, Poland is still catching up to get closer to the average value of EU GDP which is practically at a standstill: the Polish GDP was traveling on average $5.5 \%$ annually from 2004 to 2007, while the EU-27 GDP grew by $2.8 \%$ in the period 2008-2012, as a result of the recession, the Polish growth went down to $2.8 \%$ of the annual average, while the EU -27 marked a loss of $0.1 \%$. For 2013, there is a forecast of GDP growth of $0.1 \%$ EU -27, which is expected to rise to 1,6\% in 2014: estimates of growth for the Polish GDP speak about 1,5\% for 2013 and $2.5 \%$ in 2014 with further recovery (Foreign Ministry 2013) (Tab. 5).

Table 5. Poland's statistical profile: production and income, economic growth, economic structure, Government deficits and debt (trends 2005-2012)

\begin{tabular}{|c|c|c|c|c|c|c|c|c|c|}
\hline & Unit & 2005 & 2006 & 2007 & 2008 & 2009 & 2010 & 2011 & 2012 \\
\hline \multicolumn{10}{|l|}{ Production and income } \\
\hline GDP per capita & $\begin{array}{l}\text { USD current } \\
\text { PPs }\end{array}$ & 13,786 & 15,057 & 16,750 & 18,025 & 18,796 & 19,862 & 21,138 & 22,167 \\
\hline $\begin{array}{l}\text { Gross national income } \\
\text { (GNI) per capita }\end{array}$ & $\begin{array}{l}\text { USD current } \\
\text { PPPs }\end{array}$ & 13,516 & 14,674 & 16,151 & 17,662 & 18,144 & 19,103 & 20,262 & 21,235 \\
\hline $\begin{array}{l}\text { Household disposable } \\
\text { income }\end{array}$ & $\begin{array}{l}\text { Annual } \\
\text { growth (\%) }\end{array}$ & 1.5 & 4.8 & 4.2 & 4.0 & 4.7 & 2.2 & 0.4 & -0.1 \\
\hline \multicolumn{10}{|l|}{ Economic growth } \\
\hline Real GDP growth & $\begin{array}{l}\text { Annual } \\
\text { growth (\%) }\end{array}$ & 3.6 & 6.2 & 6.8 & 5.1 & 1.6 & 3.9 & 4.5 & 1.9 \\
\hline
\end{tabular}




\begin{tabular}{|c|c|c|c|c|c|c|c|c|c|}
\hline & Unit & 2005 & 2006 & 2007 & 2008 & 2009 & 2010 & 2011 & 2012 \\
\hline $\begin{array}{l}\text { Net saving rate in } \\
\text { household disposable } \\
\text { income }\end{array}$ & $\%$ & 5.9 & 6.5 & 4.6 & -0.3 & 6.8 & 6.1 & -0.2 & 2.6 \\
\hline $\begin{array}{l}\text { Gross fixed capital } \\
\text { formation }\end{array}$ & $\%$ of GDP & 6.5 & 14.9 & 17.6 & 9.6 & -1.2 & -0.4 & 8.5 & -1.7 \\
\hline \multicolumn{10}{|c|}{ Economic structure - value added } \\
\hline $\begin{array}{l}\text { Agriculture, forestry, } \\
\text { fishing: share of real } \\
\text { value added }\end{array}$ & $\%$ & 4.6 & 4.3 & 4.3 & 3.7 & 3.6 & 3.7 & 4.0 & 3.9 \\
\hline $\begin{array}{l}\text { Industry: share of real } \\
\text { value added }\end{array}$ & $\%$ & 24.6 & 24.6 & 24.4 & 24.0 & 24.6 & 24.1 & 24.8 & 24.6 \\
\hline $\begin{array}{l}\text { Services: share of real } \\
\text { value added }\end{array}$ & $\%$ & 17.1 & 17.3 & 17.9 & 18.2 & 16.6 & 16.9 & 17.0 & 17.2 \\
\hline \multicolumn{10}{|c|}{ Government deficith and debt } \\
\hline Government deficith & $\%$ of GDP & -4.1 & -3.6 & -1.9 & -3.7 & -7.5 & -7.9 & -5.0 & -3.9 \\
\hline $\begin{array}{l}\text { General government } \\
\text { debt }\end{array}$ & $\%$ of GDP & 54.1 & 54.2 & 50.4 & 55.5 & 57.6 & 61.4 & 61.6 & 63.0 \\
\hline $\begin{array}{l}\text { General government } \\
\text { revenues }\end{array}$ & $\%$ of GDP & 39.4 & 40.2 & 40.3 & 39.5 & 37.2 & 37.5 & 38.4 & 38.3 \\
\hline $\begin{array}{l}\text { General government } \\
\text { expenditures }\end{array}$ & $\%$ of GDP & 43.4 & 43.9 & 42.2 & 43.2 & 44.6 & 45.4 & 43.4 & 42.2 \\
\hline
\end{tabular}

Source: OECD.

In the last year the export was one of the strengths of the Polish economy reaching the historical value of 141.9 billion euro, of which 107.5 billion (75.8 \%) to the EU Member States, with an overall increase of $3.8 \%$, despite a dynamic drop towards its European partners with an increase of $0.9 \%$ compared to $10.9 \%$ recorded in 2011 (Fig. 2). The value of imports in 2012 reached the level of 151.7 billion euro, i.e. $0.6 \%$ less compared to the previous year (Fig. 3). The accumulation of the increasing rate of import-export in the period 2004-2012 reached $92.0 \%$ and $92.4 \%$, respectively. The accession to the EU, however, did not affect the trade with the eastern countries: the export-import from the $7.0 \%$ and $9.7 \%$ in 2004 passed to $10 \%$ and $16.3 \%$ in 2012 . The industry and the agri-food sector were the exports locomotives (Fig. 4). 


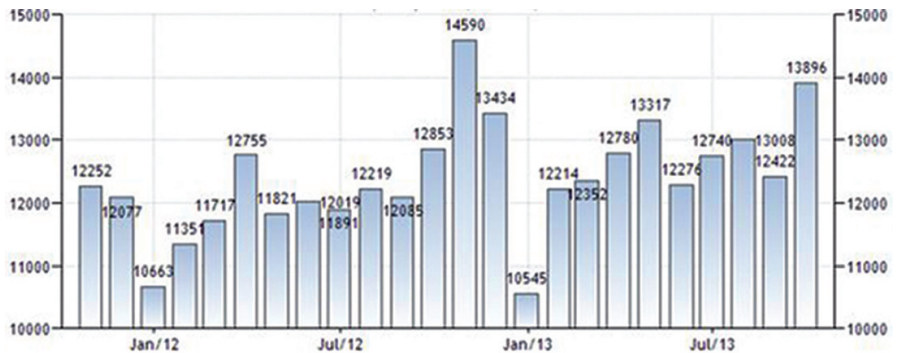

Figure 4. Poland exports by month (EUR million)

Source: www.tradingeconomics.com and Central Statistical Office of Poland.

Overall, between 1 May 2004 and 31 March 2013 about 79.2 billion euro of EU funds arrived in Poland, while 28.1 billion have been paid out as percentage of contributions and 141.7 million for restitution funds, with the balance assets of more than $€ 50$ billion. The year 2012 with 11.8 billion euro was a record year regarding the transfers of funds obtained from the EU, with an increase of $13.1 \%$ compared to 2011, amounting to $3.11 \%$ of Polish GDP (Ministry of Regional Development 2013) (Fig. 5) (Fig. 6).

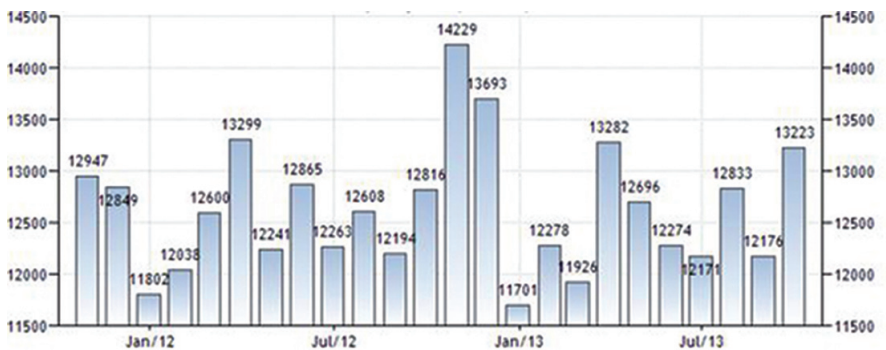

Figure 5. Poland imports by month (EUR million)

Source: www.tradingeconomics.com and Central Statistical Office of Poland.

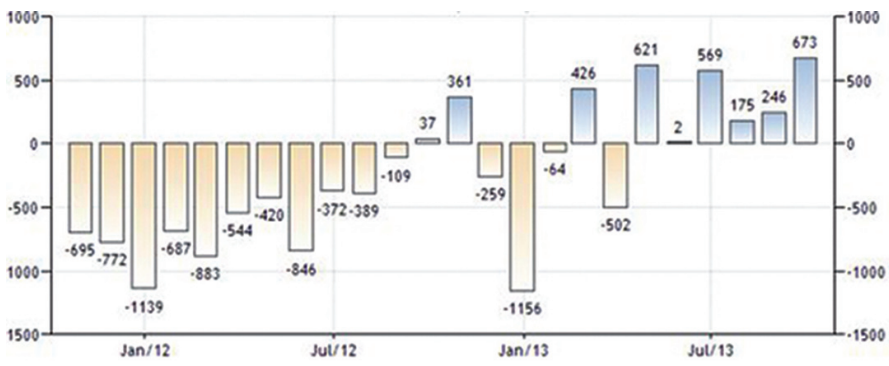

Figure 6. Poland Balance of Trade (EUR million)

Source: www.tradingeconomics.com and Central Statistical Office of Poland. 
From the Cohesion Funds, during the period 2004-2006 Poland had approximately 14.2 billion euro, of which 5.2 billion were used for the network infrastructure with construction and modernization of $314 \mathrm{~km}$ highways, $465 \mathrm{~km}$ of freeways, and renovation of $635 \mathrm{~km}$ of railway lines. On the other hand, in the period 2007-2013 it received $€ 67.3$ billion, of which 23.2 billion dedicated to the transport sector and will allow to construct $433 \mathrm{~km}$ of motorways, $900 \mathrm{~km}$ of expressways as well as over $600 \mathrm{~km}$ of railway lines by 2015 (Ministry of Regional Development 2013) (Tab. 6).

Table 6. Breakdown by Country of planned Cohesion Policy Funds' co-financing for roads between 2000 and 2013 (million euro)

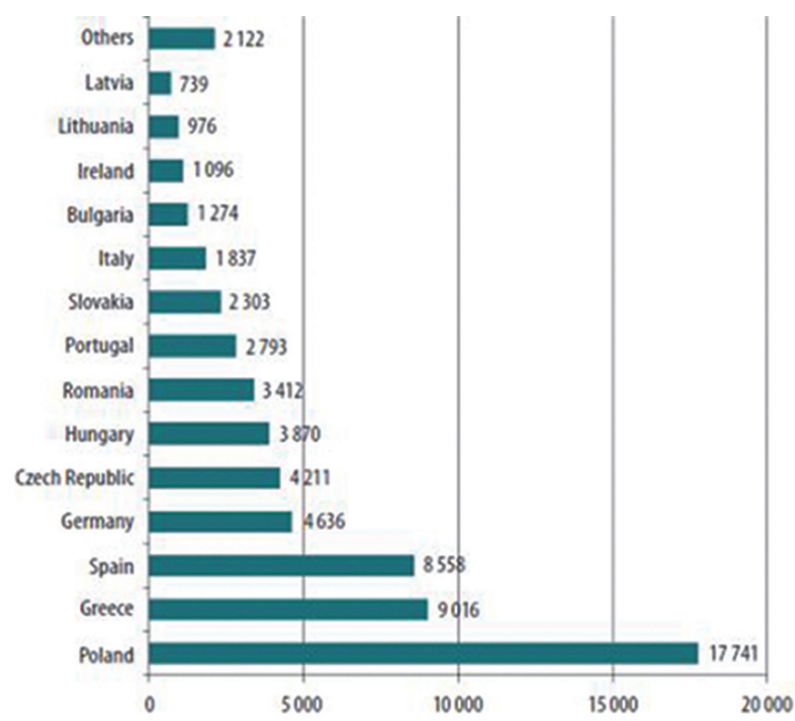

Source: European Court of Auditors 2013.

Poland has a transport sector on a well-developed level, able to compete effectively in the European market, with growth of $62 \%$ between 2006 and 2011. The entry into the EU and the Schengen area has favoured the sector thanks to the elimination of border controls. Poland has established the European record in the last year, ahead of Spain and Germany in international transport with 100922 $000000 \mathrm{t} / \mathrm{km}$, and comes the second after Germany with regard to the transport sector in general. For example, compared to the budget of about $€ 65$ billion from the ERDF and the Cohesion Fund to co-finance the construction and rehabilitation of roads for the period 2000-2013, the European Court of Auditors in 2013 has audited 24 investment projects including 6 of them implemented in Poland (European Court of Auditors 2013) (Tab. 7). 
Table 7. Overview of audited Projects in Poland

\begin{tabular}{|c|c|c|c|c|c|}
\hline $\begin{array}{l}\text { Country } \\
\text { and } \\
\text { regions }\end{array}$ & $\begin{array}{c}\text { Name of the } \\
\text { project }\end{array}$ & $\begin{array}{l}\text { Total cost } \\
\text { (euro) }\end{array}$ & $\begin{array}{c}\text { EU } \\
\text { co-finansing } \\
\text { (euro) }\end{array}$ & $\begin{array}{c}\text { Traffic } \\
\text { volume } \\
\text { as AADT }\end{array}$ & Short description of the project \\
\hline \multirow{3}{*}{ 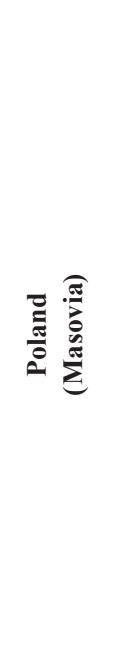 } & $\begin{array}{l}\text { Arynow bypass } \\
\text { on a road DK } 50 \\
(1.942 \mathrm{~km})\end{array}$ & $12,481,450$ & $\begin{array}{r}7,921,600 \\
(63 \%)\end{array}$ & 11,800 & $\begin{array}{l}\text { The project was a continuation of } \\
\text { the renovation of the road DK } 50 \text {, } \\
\text { as the first part was co-financed by } \\
\text { the World Bank. The project created } \\
\text { crucial connection between the } \\
\text { DK } 50 \text { and National Road No } 2 \text {. }\end{array}$ \\
\hline & $\begin{array}{l}\text { Express Road } \\
\text { S8, section } \\
\text { Radzymin-Wysz- } \\
\text { ków, including } \\
\text { Wyszków bypass } \\
(28.336 \mathrm{~km})\end{array}$ & $216,444,000$ & $\begin{array}{r}140,197,790 \\
(83 \%)\end{array}$ & 19,701 & $\begin{array}{l}\text { A new greenfield express road that } \\
\text { leads from Warsaw towards north- } \\
\text { eastern Poland. The road continues } \\
\text { as an ordinary two-lane trunk road. } \\
\text { Thoroughly adited section } 12.8 \mathrm{~km} \\
\text { bypass of Wyszków }\end{array}$ \\
\hline & $\begin{array}{l}\text { Express Road } \\
\text { S7 section } \\
\text { Białobrzegi-Jed- } \\
\text { linsk (13.652 km) }\end{array}$ & $118,022,250$ & $\begin{array}{r}85,257,005 \\
(72 \%)\end{array}$ & 24,837 & $\begin{array}{l}\text { Upgrade of national road to express } \\
\text { road standards.Continuation of } \\
\text { previous project on the same road. } \\
\text { Includes collecting roads for local } \\
\text { traffic. }\end{array}$ \\
\hline \multirow{3}{*}{ 逽 } & $\begin{array}{l}\text { Motorway A1 } \\
\text { section Sosnica- } \\
\text {-Belk }(15.411 \mathrm{~km})\end{array}$ & $307,887,511$ & $\begin{array}{r}193,803,465 \\
(63 \%)\end{array}$ & 9,374 & $\begin{array}{l}\text { First section of new motorway that } \\
\text { connect Central Poland to Czech } \\
\text { Republic. Out of the audited sample } \\
\text { of } 24 \text { projects the A1 was the only } \\
\text { one awarded to a non-domestic } \\
\text { bidder. }\end{array}$ \\
\hline & $\begin{array}{l}\text { National Road } \\
\text { nr } 43 \text { in the city } \\
\text { of Częstochowa } \\
(1.4 \mathrm{~km})\end{array}$ & $14,028,195$ & $\begin{array}{r}9,401,244 \\
(67 \%)\end{array}$ & 31,525 & $\begin{array}{l}\text { New bridge over the railway tracks } \\
\text { and large upgrade of the national } \\
\text { road in the territory of Częstochowa }\end{array}$ \\
\hline & $\begin{array}{l}\text { National Road } \\
\text { nr } 79 \text { in the city } \\
\text { of Jaworzno } \\
(2.92 \mathrm{~km})\end{array}$ & $16,880,016$ & $\begin{array}{r}761,766 \\
(4.5 \%)\end{array}$ & 12,900 & $\begin{array}{l}\text { New alignment of the road DK in } \\
\text { the city of Jaworzno, bypassing } \\
\text { the transit traffic from the city } \\
\text { centre. Was procured as a lump } \\
\text { sum contract though no unit cost } \\
\text { information is available }\end{array}$ \\
\hline
\end{tabular}

Source: European Court of Auditors 2013.

The evaluations have found how the projects co-financed by the EU in Silesia and Mazovia were characterized by a proper realization and a significant reduction in the time construction compared to other countries in spite of partially higher costs justified by the need for security.

An important effect of the entry of Poland into the European Union is associated with the flow of capital from abroad, coming largely from the migrants working in the EU MS: from May 2004 until December 31, 2012 the individuals' money transfers amounted almost to 32 billion euro that was equal to $86 \%$ of the flow of money from abroad, with a peak of 4.6 billion euro in 2007 . Most of 
the labour migrants reside in the United Kingdom (30.3\%), followed by Germany (22.8\%), Ireland (5.8\%) and Netherlands (4.6\%). Overall, from May 2004 to March 31, 2013 more than 111.5 billion euro were transferred in Poland, including EU funds and capital from abroad (Ministry of Foreign Affairs, Embassy of Italy 2013).

Between 2003 and 2008, the unemployment rate in Poland continued to decline: on the other hand it has risen to $12.1 \%$ since 2009 due to the crisis. In 2012 it stood at $13.4 \%$, an increase of $0.9 \%$ compared to 2011. Unemployment in Poland has dropped to 13\% in August 2013 despite the economic downturn. In July, unemployment was 13.1\%. Labour Minister Władysław Kosiniak-Kamysz showed that even if the growth of unemployment is normal - given the economic crisis of the EU - the increase will be lower in this period than in other years. The Polish government, however, had to revise downwards the growth estimates for this year from $2.2 \%$ to $1.5 \%$ (Fig. 7 ).

\section{Allocations of EU funds for CEE countries in 2007-2013 ( $€$ billions)}

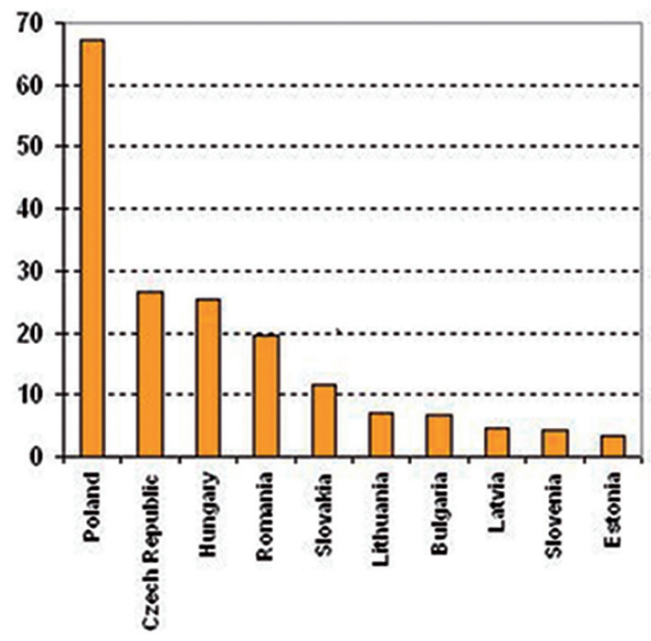

Figure 7. Structural Funds in the new Member States.

Source: www.inforse.org.

\section{The government guidelines of the Partnership Agreement between Poland and the European Commission and the financial perspective 2014-2020}

According to the surveys carried out over the last year, the Poles are in favour of their membership in the EU with an average between 73 and $78 \%$, a figure higher than ten percentage points compared to the European average, but they are also strong opponents of the entrance of their country in the euro area with averages ranging between 64 and 70\%; the data are closely linked to the effects of the crisis and in this sense we should also read the increment of the distrust level which that rose from $18 \%$ in 2007 to $42 \%$ in 2012 (Hanzelewicz 2013) in the European organism in recent years.

As mentioned, on February 9, 2013, the European Commission has approved the draft of the EU multi-annual budget 2014-2020 according to which Poland would receive $€ 72.9$ billion for the Cohesion Policy (compared to $€ 67.3$ billion allocated in the 2007-2013 programming) and $€ 28.5$ billion for the Common Agricultural Policy (compared to the current $€ 26.9$ billion). Pending the approval by 
the European Parliament, the Polish Ministry of Regional Development had already prepared three documents which provide a basis for the implementation of the funds: the Partnership Agreement between Poland and the European Commission, the Operational Programmes regarding specific areas of implementation of the funds and Territorial Agreement which governs the cooperation between the central government and the governments of Polish regions.

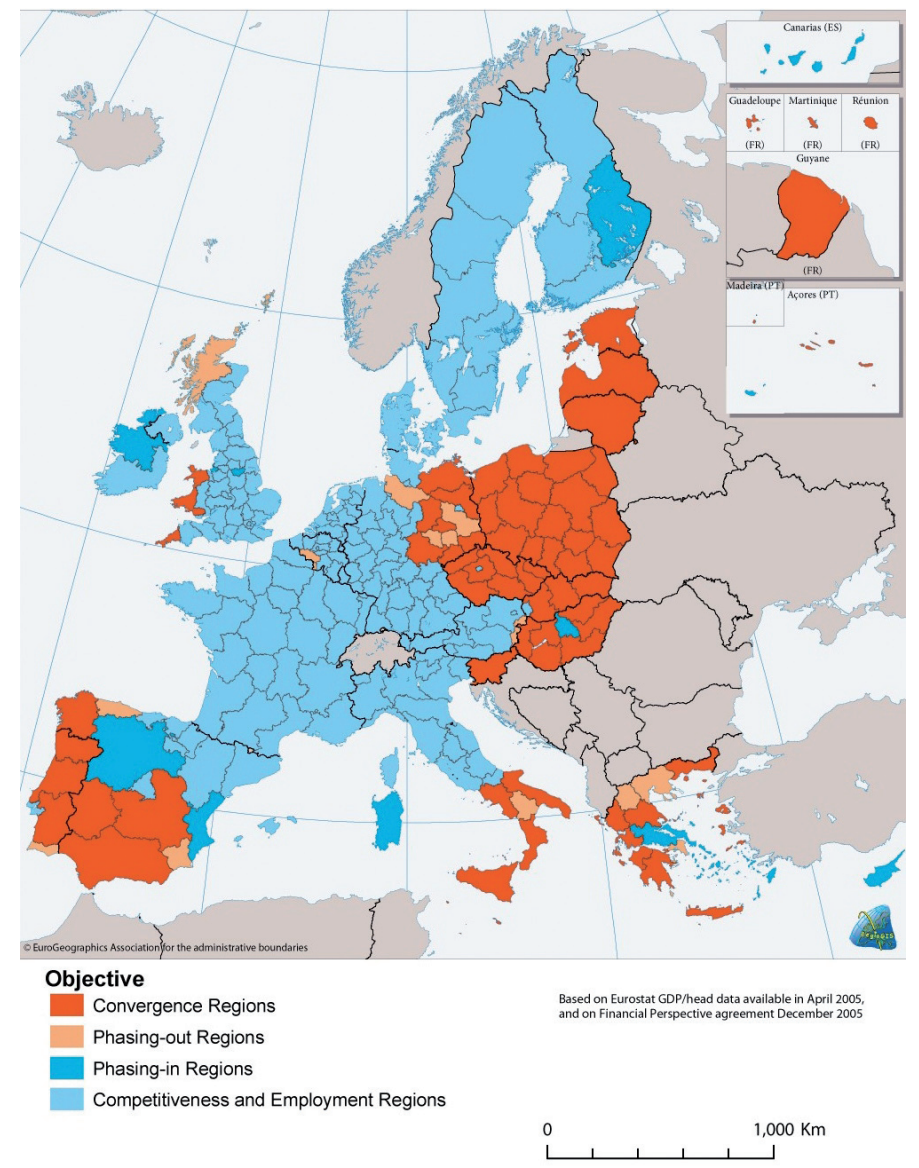

Figure 8. Structural Funds 2007-2013: Convergence and Regional Competiveness Objectives Source: www.nordregio.se.

Particularly, on January 15, 2013, the Polish government has approved the guidelines for the Partnership Agreement that will form the basis for negotiations between Poland and the European Commission with regard to EU funds for the new EU budget. According to these guidelines the EU funds allocated to Poland will be invested in three strategic areas, in accordance with the "Strategy of Development of the State 2020" in September 2012: strengthening the competitiveness of the economy, improving social and territorial cohesion, and making the State more efficient and effective. For this purpose the following programmes will be established: 8 national programs out of which one is dedicated to Eastern Poland and one dedicated to the digitization (e.g. broadband internet, e- government, e-services), 16 programs at the regional level and territorial co-operation 
programs. Compared to the current situation the major innovations in the funds distribution include the following: increasing the funding for regional projects, increasing the tools to be repaid (e.g. loans, guarantee funds) in employers' favour, more support for investments aimed at innovation growth in the economy (e.g. collaboration in R \& D with business) and the transition towards an economy of low carbon emissions (Ministerstwo Rozwoju Regionalnego 2013a, 2013b, 2013c).

The Ministry of Regional Development presented its proposal for the distribution of funds among the Polish regions in the Financial Perspective 2014-2020. Overall, the regions will receive $€ 28.9$ billion, an amount significantly higher than the funds allocated in the current financial perspective 2007-2013 (€ 19.8 billion). According to the ministerial proposal the allocation will help in particular the division of Silesia ( $€ 2.78$ billion) and the Malopolska ( $€ 2.39$ billion), while the Lubusz ( $€ 0.72$ billion) and Opole ( $€ 0.75$ billion) will receive lower amounts. The change in the total amount results from the fact that the Ministry has increased the percentage of participating regions in the management of the Structural Fund. The allocated sum for each region is calculated using a new algorithm that helps the poorest regions, the most populous, with higher unemployment and lower GDP per capita. The change of the algorithm aroused protests of some Marshals who were not satisfied with the amounts allocated to their regions.

Table 8. Poland's statistical profile: taxes, trade, foreign direct investments, price and interest rates, purchasing power and exchange rates, energy supply and price (trends 2005-2012)

\begin{tabular}{|c|c|c|c|c|c|c|c|c|c|}
\hline & Unit & 2005 & 2006 & 2007 & 2008 & 2009 & 2010 & 2011 & 2012 \\
\hline \multicolumn{10}{|l|}{ Taxes } \\
\hline Total tax revenue & $\%$ of GDP & 33.0 & 34.0 & 34.8 & 34.2 & 31.7 & 31.7 & .. & .. \\
\hline $\begin{array}{l}\text { Taxes on income and } \\
\text { profits }\end{array}$ & $\%$ of GDP & 6.4 & 7.0 & 8.0 & 8.1 & 6.9 & 6.5 & .. & .. \\
\hline $\begin{array}{l}\text { Taxes on good and } \\
\text { services }\end{array}$ & $\%$ of GDP & 12.7 & 13.3 & 13.0 & 13.0 & 11.7 & 12.5 & .. & .. \\
\hline $\begin{array}{l}\text { Taxes on the average } \\
\text { worker }\end{array}$ & $\begin{array}{l}\% \text { of labour } \\
\text { cost }\end{array}$ & 28.4 & 28.7 & 27.8 & 25.0 & 24.4 & 24.5 & 24.5 & 24.6 \\
\hline \multicolumn{10}{|l|}{ Trade } \\
\hline $\begin{array}{l}\text { Imports of goods and } \\
\text { services }\end{array}$ & $\%$ of GDP & 37.8 & 42.2 & 43.6 & 43.9 & 39.4 & 43.4 & 46.2 & 46.4 \\
\hline $\begin{array}{l}\text { Exports of goods and } \\
\text { services }\end{array}$ & $\%$ of GDP & 37.1 & 40.4 & 40.8 & 39.9 & 39.4 & 42.2 & 45.1 & 46.7 \\
\hline $\begin{array}{l}\text { Good trade balance: } \\
\text { exports minus imports } \\
\text { of good }\end{array}$ & Bln USD & -12.2 & -16.1 & -25.4 & -38.6 & -10.5 & $-17,1$ & -19.7 & .. \\
\hline Imports of goods & Bln USD & 101.5 & 125.6 & 164.2 & 210.5 & 147.1 & 174.1 & 209.2 & 191.4 \\
\hline Exports of goods & Bln USD & 89.4 & 109.6 & 138.8 & 171.9 & 136.6 & 157.1 & 188.1 & 179.6 \\
\hline $\begin{array}{l}\text { Service trade balance: } \\
\text { exports minus imports } \\
\text { of services }\end{array}$ & Bln USD & 0.7 & 0.7 & 4.8 & 5.0 & 4.8 & 3.1 & 5.7 & 6.0 \\
\hline Imports of services & Bln USD & 15.5 & 19.9 & 24.2 & 30.5 & 24.2 & 29.6 & 31.9 & 31.9 \\
\hline
\end{tabular}




\begin{tabular}{|c|c|c|c|c|c|c|c|c|c|}
\hline & Unit & 2005 & 2006 & 2007 & 2008 & 2009 & 2010 & 2011 & 2012 \\
\hline Exports of services & Bln USD & 16.3 & 20.6 & 28.9 & 35.5 & 29.0 & 32.7 & 37.6 & 37.9 \\
\hline $\begin{array}{l}\text { Current account balance } \\
\text { of payments }\end{array}$ & $\%$ of GDP & -2.4 & -3.8 & -6.2 & -6.5 & -4.0 & -5.1 & -5.0 & -3.7 \\
\hline \multicolumn{10}{|c|}{ Foreign direct investment (FDI) } \\
\hline Outward FDI stocks & Mln USD & 6,307 & 14,393 & 21,318 & 24,092 & 29,304 & 44,444 & 52,849 & 57,367 \\
\hline Inward FDI stocks & Mln USD & 90,869 & 125,788 & 178,418 & 164,290 & 185,182 & 215,639 & 203,111 & 235,113 \\
\hline $\begin{array}{l}\text { Inflows of foreign direct } \\
\text { investment }\end{array}$ & Mln USD & 10,299 & 19,599 & 23,582 & 14,833 & 12,936 & 13,879 & 20,652 & 6,067 \\
\hline $\begin{array}{l}\text { Outflows of foreign } \\
\text { direct investment }\end{array}$ & Mln USD & 3,405 & 8,864 & 5,410 & 4,413 & 4,701 & 7,228 & 8,169 & 728 \\
\hline
\end{tabular}

\section{Prices and interest rates}

\begin{tabular}{|l|l|r|r|r|r|r|r|r|r|}
\hline Inflation rate: all items & $\begin{array}{l}\text { Annual } \\
\text { growth \% }\end{array}$ & 2.2 & 1.3 & 2.4 & 4.2 & 3.8 & 2.6 & 4.2 & 3.6 \\
\hline $\begin{array}{l}\text { Inflation rate: all items } \\
\text { non food non energy }\end{array}$ & $\begin{array}{l}\text { Annual } \\
\text { growth \% }\end{array}$ & 1.4 & 0.7 & 1.1 & 2.2 & 3.0 & 1.6 & 2.3 & 1.4 \\
\hline Inflation rate: food & $\begin{array}{l}\text { Annual } \\
\text { growth \% }\end{array}$ & 2.2 & 0.7 & 4.5 & 5.6 & 4.7 & 2.8 & 5.2 & 4.2 \\
\hline Inflation rate: energy & $\begin{array}{l}\text { Annual } \\
\text { growth \% }\end{array}$ & 5.7 & 5.1 & 3.7 & 8.7 & 6.0 & 5.8 & 8.9 & 7.6 \\
\hline $\begin{array}{l}\text { Producer Price Indices } \\
\text { (PPI): manufacturing }\end{array}$ & $\begin{array}{l}\text { Annual } \\
\text { growth \% }\end{array}$ & 1.4 & 1.9 & 3.6 & 3.4 & -2.6 & 2.9 & 8.6 & 3.3 \\
\hline Long-term interest rates & \% & 5.22 & 5.23 & 5.48 & 6.07 & 6.12 & 5.78 & 5.96 & 5.00 \\
\hline
\end{tabular}

\section{Purchasing power and exchange rates}

\begin{tabular}{|l|l|r|r|r|r|r|r|r|r|}
\hline $\begin{array}{l}\text { Purchasing power } \\
\text { parities }\end{array}$ & $\begin{array}{l}\text { PLN per } \\
\text { USD }\end{array}$ & 1.87 & 1.85 & 1.84 & 1.86 & 1.87 & 1.85 & 1.88 & 1.87 \\
\hline Exchange rates & $\begin{array}{l}\text { PLN per } \\
\text { USD }\end{array}$ & 3.24 & 3.10 & 2.77 & 2.41 & 3.12 & 3.02 & 2.96 & 3.26 \\
\hline Indices of price levels & OECD=100 & 57 & 60 & 64 & 73 & 59 & 60 & 60 & 57 \\
\hline
\end{tabular}

\section{Energy supply and prices}

\begin{tabular}{|l|l|r|r|r|r|r|r|r|r|}
\hline $\begin{array}{l}\text { Total primary energy } \\
\text { supply (TPES) }\end{array}$ & Mtoe & 92.4 & 97.2 & 96.8 & 97.9 & 94.0 & 101.5 & 102.6 &.. \\
\hline $\begin{array}{l}\text { TPES per unit of GDP at } \\
2000 \text { prices and PPPs }\end{array}$ & $\begin{array}{l}\text { Toe per } 1000 \\
\text { USD }\end{array}$ & 0.18 & 0.17 & 0.16 & 0.16 & 0.15 & 0.15 & 0.15 &.. \\
\hline $\begin{array}{l}\text { Renewables' contribu- } \\
\text { tion to total primary } \\
\text { energy supply }\end{array}$ & \% & 4.8 & 4.8 & 5.0 & 5.7 & 6.7 & 7.2 & 7.8 &.. \\
\hline $\begin{array}{l}\text { Crude oil import prices } \\
\text { USD per } \\
\text { barrel }\end{array}$ &.. &.. &.. & 94.02 & 60.83 & 77.89 & 109.58 &.. \\
\hline
\end{tabular}


Since February 22, 2013, a new online tool issued by the Polish Ministry of Regional Development has been activated. It facilitates researching for projects in progress or completed under the Operational Programme "Innovative Economy" (OP). This service allows to search for projects based on various custom criteria (location, title and value of the project, measurement in which it was made, name and type of beneficiary, etc.) to display the location of sought-after projects through an interactive map. The information available through the so-called "Interactive Database of Beneficiaries" (Interaktywna Baza Beneficjentów) will be updated periodically.

In June 2013, the European leaders have developed the Compact Growth in the name of recovery and European competitiveness. But when it comes to dip into their wallet, as in the case of the 2014-2020 multiannual financial framework being negotiated, things get complicated (European Commission 2013).

So as happened in 2007-2013, Poland will be the Member State which will benefit the most from the European funds allocated to cohesion. Each EU Member State receives every six years its budget which is determined on the basis of an objective socio-economic parameter which is represented by the ratio of the average GDP of the Member States and the proper national GDP. Since Poland is the most populous State among those which have joined the EU since 2004, and at the same time has a GDP still relatively low compared to the European average, it reaches a factor that justifies a so generous assignment.

A special mention must be made of the ability to absorb by the Polish authority. Poland proved itself to be very efficient in spending the received funds.

"Deal is Done!" this is how Herman Van Rompuy, the President of the EU Council, announced the closing of the agreement on the 2014-2012 budget on twitter after a marathon that lasted for 25 hours. An agreement that will provide 960 billion commitments and 908 payments. Later, at a press conference, Van Rompuy said that the innovation of this European budget is that it is the first multiannual financial framework which is falling in the Community's history. Less than $€ 34$ billion disappointed those who hoped to see the EU budget as the way to escape from the clutches of the "national fiscal compact" and to jumpstart the economy of the Old Continent in Keynesian key. Except for the Erasmus program for students. For Poland the agreement made in Brussels is a satisfying result. The Prime Minister Tusk achieved great success for Poland obtaining EU funds to $€ 106$ billion that will continue the investment in infrastructure, already begun with the previous programming of funds for 2007-2013 (Da Rold 2013).

Table 9. Poland's statistical profile: employment and unemployment (trends 2005-2012)

\begin{tabular}{|l|l|r|r|r|r|r|r|r|r|}
\hline & Unit & $\mathbf{2 0 0 5}$ & $\mathbf{2 0 0 6}$ & $\mathbf{2 0 0 7}$ & $\mathbf{2 0 0 8}$ & $\mathbf{2 0 0 9}$ & $\mathbf{2 0 1 0}$ & $\mathbf{2 0 1 1}$ & $\mathbf{2 0 1 2}$ \\
\hline Employment & 20.9 & 24.0 & 25.8 & 27.3 & 26.8 & 26.4 & 24.9 & 24.7 \\
\hline $\begin{array}{l}\text { Employment rate in } \\
\text { population aged 15-24 }\end{array}$ & $\%$ & 69.5 & 71.8 & 74.9 & 77.5 & 77.6 & 77.2 & 77.3 & 77.2 \\
\hline $\begin{array}{l}\text { Employment rate in } \\
\text { population aged 25-54 }\end{array}$ & $\%$ & 29.1 & 28.1 & 29.7 & 31.6 & 32.3 & 34.1 & 36.9 & 38.7 \\
\hline $\begin{array}{l}\text { Employment rate in } \\
\text { population aged 55-64 }\end{array}$ & $\%$ & 11.7 & 10.8 & 10.1 & 9.3 & 8.7 & 8.7 & 8.3 & 8.0 \\
\hline $\begin{array}{l}\text { Incidence of part-time } \\
\text { employment }\end{array}$ & $\%$ & & & & & & & & \\
\hline
\end{tabular}




\begin{tabular}{|c|c|c|c|c|c|c|c|c|c|}
\hline & Unit & 2005 & 2006 & 2007 & 2008 & 2009 & 2010 & 2011 & 2012 \\
\hline $\begin{array}{l}\text { Self-employment rate: } \\
\text { total employment }\end{array}$ & $\%$ & 25.8 & 24.4 & 23.5 & 22.9 & 22.7 & 23.0 & 22.9 & 22.4 \\
\hline $\begin{array}{l}\text { Self-employment rate, } \\
\text { men: male employment }\end{array}$ & $\%$ & 27.9 & 26.6 & 25.5 & 25.0 & 24.9 & 25.3 & 25.3 & 25.0 \\
\hline $\begin{array}{l}\text { Self-employment } \\
\text { rate, women: female } \\
\text { employment }\end{array}$ & $\%$ & 23.1 & 21.8 & 20.9 & 20.4 & 20.1 & 20.1 & 19.8 & 19.2 \\
\hline \multicolumn{10}{|l|}{ Unemployment } \\
\hline $\begin{array}{l}\text { Unemployment rate: } \\
\text { total labour force }\end{array}$ & $\%$ & 17.9 & 14.0 & 9.6 & 7.0 & 8.1 & 9.7 & 9.7 & 10.1 \\
\hline $\begin{array}{l}\text { Unemployment rate, } \\
\text { men: male labour force }\end{array}$ & $\%$ & 16.6 & 13.0 & 9.0 & 6.4 & 7.8 & 9.3 & 9.0 & 9.4 \\
\hline $\begin{array}{l}\text { Unemployment rate, } \\
\text { women: female labour } \\
\text { force }\end{array}$ & $\%$ & 19.4 & 15.1 & 10.4 & 7.9 & 8.6 & 10.1 & 10.4 & 10.9 \\
\hline $\begin{array}{l}\text { Long-term } \\
\text { unemployment: total } \\
\text { unemployed }\end{array}$ & $\%$ & 52.2 & 50.4 & 45.9 & 29.0 & 25.2 & 25.5 & 31.6 & 34.8 \\
\hline
\end{tabular}

Source: OECD.

\section{Strategy of Development of the State 2020 and examples of good Polish practice}

On 25 September 2012, the Polish government approved the "Strategy of Development of the State 2020," a medium-term strategy which sets out the most important jobs that need to be done in the coming years to accelerate the development of the country and achieve social and economic objectives set (Republic of Poland 2012). The development should focus on three strategic areas: 1) competitive economy, 2) social and territorial cohesion, 3) efficient and effective state. Within the priorities some key indicators are highlighted.

Progress in achieving the priorities will be measured also in terms of other important indicators: the employment rate of people aged 20-64 years, the risk of poverty or social exclusion and also the proportion of renewable energy in the total energy consumption. This document constituted a reference point for other documents related to the financial perspective of Poland in the new EU budget for the years 2014-2020. It is expected that the first step to implement the strategy would consist in concentration of financial resources on the areas of development, including, in particular, education, health, culture, telecommunications, transportation and environmental infrastructures, $\mathrm{R} \& \mathrm{D}$ and modernization of agriculture. To achieve these goals a spending review is fundamental to avoid an increase in the public deficit. However, the implementation of the Strategy will require an investment of significant public resources, not only national but also those of the community. According to estimates, with stable macroeconomic fundamentals, public expenditure in 2020 is expected to reach $17.6 \%$ of Polish GDP, to which would be added the EU fund amounting to $23-25 \%$ of the total expenditure. 
Among the projects of particular interest there were those associated with the production and use of low emissions energy, development of public transport networks, railway network and the increase in the level of digitalization. The Ministry also highlighted that substantial funding will be allocated exclusively to the "regional governments".

On October 24, 2012, in Kielce a contract was signed for the co-financing of the project entitled "Eliminating barriers to development - the bridge over the Vistula" associated with the reconstruction of the regional road n. 764 and connection with the regional road n. 875 worth over 390 million PLN (approx. $€ 94.9$ million at the average exchange rate for October) of which 327 million PLN (approx. $€ 79.6$ million) allocated by the EU.

The project will be implemented with the support of funds under the Operational Programme Development of Eastern Poland and should be completed in the fourth quarter of 2014. The new route with the bridge (area Połaniec), once realized, will connect the two districts Mielecki (Podkarpackie) and Staszowski (Świętokrzyskie region) and facilitate access to the Special Economic Zone Euro-Park Mielec and improve the communication with Ukraine and Slovakia. The project will be implemented by a Polish consortium of three companies: Mosty-Lód, Vistal Gdynia and Kieleckie Przedsiębiorstwo Robót Drogowych (Italian Trade Agency 2012).

The annual survey commissioned by the Polish Agency of Information and Foreign Investments (Polska Agencja Informacji i Inwestycji Zagranicznych - PAIIZ) shows that for the foreign investors already operating in Poland the main advantages offered by the country include the following: the size of the market (4.2 points out of 5), political stability (4.1 points out of 5) and the availability of labour force (4.0 points out of 5) (PAIIZ 2012). It should be emphasized that the Polish market is treated as a part of the larger European market more than as a separate one. Poland is generally appreciated as a place to start an economic activity; this category has received 4 out of 5 possible points. Entrepreneurs, however, also identified weaknesses in the Polish market: the lack of efficiency of the commercial courts, especially slowness of Justice and the lack of clarity of the regulations. 84 large companies participated at the survey, of which 70 are companies with foreign capital. Despite the crisis, $89 \%$ of these companies plan to invest over the course of 2013.

\section{"Geostability", geopolitical and geostrategic value of Poland}

The importance of Poland to the European Union is especially that of being a good example of the success of enlargement: a country which the benefits of the membership had the effect of dampening the Euroscepticism and brought stability both on the economic and political scale. As for former, the economic growth, stable at around $4 \%$, is a significant figure in times of crisis, which equals the solidity of the system, partially due to the increasingly close trade relations with Germany. Moreover, the boom of recent years has increased the Poles' trust in their own resources and helped them to overcome that sort of inferiority complex caused by prolonged internal division and separation from Europe of which Poland feels an integral part. However, a few problems still remain that prevent more rapid development, such as the very structure of the system, technologically not too much advanced and dominated by small family businesses which cannot guarantee jobs to a growing number of young graduates who are forced to emigrate thereby. At the political level, the liberal-conservative government of Tusk, who has led the country since 2007, and the President of the Republic, Komorowski, elected in 2010, are an expression of the political force, the Civic Platform: a situation that favours the inter-institutional dialogue to the benefit of the governance of the country.

From the geopolitical point of view, Poland is first of all a highly strategic country and is based on this awareness that also plays the role of a bridge between the EU and the countries to the East 
of the European Union, in particular those States which are associated in Brussels through the Eastern Partnership agreed in Prague in May 2009 (Council of the European Union 2009). On the other hand, thanks to the Polish initiative this agreement that was signed is a branch of the European Neighbourhood Policy and it involves countries with which Warsaw shares the legacy of the Soviet past: Armenia, Azerbaijan, Georgia, Moldova, Ukraine and Belarus. In this task Poland may be particularly effective, because of that world it is for now the best example of an achieved development. The re-launch of the Eastern Partnership the success of which is, however, bound to an unavoidable increase in funding for this project consists of some essential actions proposed by Poland: first of all, provision of benefits in granting visas and implementation of measures of modernization in the concerned countries in order to stimulate the acceptance of the European model. A step forward in this direction could have been achieved by concluding a free trade agreement between the EU and Ukraine, an early sign of rapprochement which would have opened the way for similar treaties with other countries in the area, in view of their future membership, and at the same time a result of which Poland could have boasted internationally.

But on November 21 Ukraine has turned its back on Europe, by giving up on the signature of the Association Agreement with the EU at the summit on the Eastern Partnership of Vilnius and yielding to political and economic pressures of Russia. The Association Agreement thrilled not only the foreign media, but also the Ukrainian population. For the Polish press the government has confirmed the thesis of the European politicians convinced that Yanukovich was simply taking advantage of the European card for getting a better deal with Russia (Czech 2013). The President Komorowski, by commenting on the stop of Kiev to the Association Agreement with the EU, has clearly shown that Brussels has committed an error of judgment on the EU-Ukraine relations issue. The real problem, in fact, is not the matter of Yulia Tymoshenko, but it's the policy of blackmail and pressure exerted by Russia; he also pointed out that Poland will work for a firm and wise reaction of the EU to the diktat of Moscow on Ukraine (Czech \& Kursk 2013). Meanwhile, the demonstrations by the opposition parties continue along with the pro-European Ukrainian population, which have resulted in violent clashes with the police.

\section{Governance and multilevel governance in the European perspective. The Polish decentralism as an example}

The issue of governance is closely linked to a reflection on the role and functions of Public Administration as an essential actor of territorial development policies. The process of Integrated Approach set in motion a number of changes in the functioning of Public Administration, developing innovation in individual and collective behaviour, in organizational models and in procedures. This resulted in the need for new skills - technical, behavioural, in relationships - and a greater ability of the Governments to "make net" with all the actors involved in order to enrich social and territorial capital through the creation of new relational goods. It is possible to distinguish different approaches to multilevel governance. The term "decentralization" refers to the transfer of certain powers from the central government to various levels of governance; a growing interest has been observed towards the concept of political decentralization, but also political differences according to special cases (particularity vs generalization).

If we focus on the characteristics of the general policies of multilevel governance, at the core of the analysis there would be the changing relationships between actors situated at different territorial levels. This implies frequent and complex interactions between the governmental actors and the increasing important dimension of non-state actors. In particular, the multilevel governance intersects 
the traditionally separated domains of internal and international policy. In the context of European integration, multilevel governance shows how the boundaries between these domains are becoming increasingly indistinguishable, and how local, regional, national and supranational governments are interrelated in political systems territorially overarching (Bekemans 2012). The multilevel governance approach describes the European Union as a political system with interconnected institutions, located at different levels; the MLG implies a shift of competences to the top (European Institutions) and to the bottom (sub-state/Regions). If it is still too early to find a real relationship EU-States-Regions in all EU States, it is possible to observe it in Poland because of the decentralization and regionalism which are crucial for the success of cohesion policy.

In Poland, as well as in Czech Republic and Slovakia, regionalization and decentralization have been a reaction to the centralism of the communist regimes (Brzezinski 2000). In Poland, the regional reform was carried out on January 1, 1999. The country was divided into 16 regions (voivodships) and three autonomous cities (Warsaw, Krakow and Łódź). The most significant element of the reform consists of the administrative subdivision of the representations in three levels of local units: municipalities (gmina), provinces (powiat) and regions (województwo). The municipality (gmina) is the first level of local administration. In Poland there are 2,489 municipalities. The provinces, also called districts (powiat), are constituted of the municipalities; there are 308 districts in Poland. The regions-voivodeships (Województwa) represent the largest administrative unit order (Fig. 8). The Polish Regions are responsible for the definition of an overall strategy for regional development and for the authorization to tighten direct relations with the regional units of the neighbouring countries. Competences and resources, particularly in the areas of health, education, assistance and security, were delegated to the Regions which gave themselves statutes. The reform is based on the principle of subsidiarity and is seen as a way to make Poland become European more quickly. The Polish approach is currently the most advanced one of self-government in the East (Duhr et al 2010). As mentioned above, there are many ethnic minorities in the eastern border in Poland: Ukrainians, Lithuanians and Belarusians. They have cultural and religious organizations and they cultivate their traditions and preserve their monuments. But better structured regionalism, based on ethnic and territorial roots, is the one of high Silesia where the German minority is established. Insufficient organized movements, there are no political parties, but the lobby is very active in the Parliament. The new region of Opole established by decentralization does not meet the needs of the Silesian who complain of an internal colonialism and still excessive power of the prefects, an expression of the continuing centralization (Białasiewicz 2002).

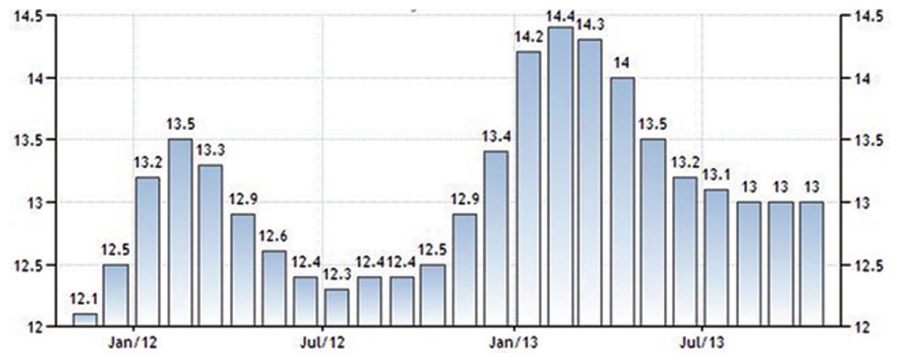

Figure 9. Poland Unemployment Rate

Source: www.tradingeconomics.com and Central Statistical Office of Poland.

In this sense, the Polish regionalism can once again serve as an example, from the European perspective, how exploit better the potential provided by the Union. 


\section{References}

Adams N., Cotella G., Nunes R., 2011, Territorial Development, Cohesion and Spatial Planning, Knowledge and Policy Development in AN Enlarged EU, Routledge, London.

Bache I., 2008, Europeanization and Multilevel Governance, Cohesion Policy in the European Union and Britain, Rowman \& Littlefield Publishers, Maryland, USA.

Bachtler J., Mendez C., 2007, Who Governs EU Cohesion Policy? Deconstructing the Reforms of the Structural Funds, in "Journal of Common Market Studies", 45(3), pp. 535-564.

Bekemans L., 2012, Intercultural Dialogue and Multi-level Governance in Europe. A Human Rights Based Approach, International Academic Publishers Peter Lang, Brussels

Bialasiewicz L., O’Loughlin J., 2002, Re-ordering Europe's Eastern frontier: Galicjan Identities and Political Cartographies on the Polish-Ukrainian Border, in Kaplan D., Hakli J., (eds) Boundaries and Place: European Borderlands in Geographical Context, London: Rowman \& Littlefield.

Bialasiewicz L., 2002, The rebirth of Upper Silesia, in "Regional and Federal Studies" 12(2): 111-132.

Boehme K., Doucet P., Komornicki T., Zaucha J., Świątek D., 2011, How to strengthen the territorial dimension of 'Europe 2020' and the EU Cohesion Policy. Background Report based on the Territorial Agenda 2020. Warsaw: Ministry of Regional Development, 2011 - 82 pp.

Bova V., 2005, Solidarnosc. Origini, sviluppo ed istituzionalizzazione di un movimento sociale, Rubettino, Catanzaro.

Brzezinski M., 2000, The Struggle for Constitutionalism in Poland (St Antony's Series), Palgrave Macmillan, London.

Camagni R., 2009, Per un concetto di capitale territoriale, in Borri D., Ferlaino F., (eds), Crescita e sviluppo regionale: strumenti, sistemi, azioni, Franco Angeli, Milano.

Commission of the European Communities, 2008, Communication from the Commission to the Council, the European Parliament, the Committee of the Regions and the European Economic and Social Committee, Green Paper on Territorial Cohesion.Turning territorial diversity into strength, Brussels, 6.10.2008, COM (2008) 616 final.

Cotella G., 2012, Cohesion and Development in the EU: A Multi-level Issue (Editorial), in "Europa XXI", 22, 2012, Institute of Geography and Spatial Organization, Warsaw, 5 pp.

Council of the European Union, 2009, Joint Declaration of the Prague Eastern Partnership Summit Prague 7 May 2009, Brussels, 7 May 2009 8435/09 (Press 78), in “www.consilium.europa.eu”.

Council of the European Union, 2012, PRESS RELEASE 3152nd Council meeting Environment, Provisional version, Brussels, 9 March 2012.

Czech M., Kursk J., 2013,Komorowski: Jeszcze Ukraina nie zginęła. Nie ma zgody na politykę szantażu, in "Gazeta Wyborcza", 26.11.2013.

Czeck M., 2013, Kres zbliżenia Ukrainy z Europa: Janukowycz wywrócit stolik, in “Gazeta Wyborcza”, 21.11.2013.

Da Rold V., 2013, Raggiunto accordo su bilancio settennale Ue, il primo al ribasso. Erasmus salvo, in "il Sole24 ore", 8 Febbraio 2013.

Dotti F.N., 2010, Being poor is not enough: the 'non-written' factors affecting of the EU structural funds, XXXI Conferenza Italiana di Scienze Regionali, Associazione Italiana di Scienze Regionali (AISRe), in www.grupposervizioambiente.it.

Duhr S., Colomb C., Nadine V., 2010, European spatial planning and territorial cooperation, Routledge, New York. 
European Commission, 2010a, Communication from the Commission to the European Parliament, the Council, the European Economic and Social Committee and the Committee of the Regions, Regional Policy contributing to smart growth in Europe 2020, Brussels, 6.10.2010, COM(2010) 553 final.

European Commission, 2010b, Communication from the Commission, EUROPE 2020, A strategy for smart, sustainable and inclusive growth, Brussels, 3.3.2010, COM(2010) 2020 final.

European Commission, 2011, Communication from the Commission to the European Parliament, the Council, The European Economic and Social Committee and the Committee of the Regions, Roadmap to a Resource Efficient Europe, Brussels, 20.9.2011, COM(2011) 571 final.

European Commission, 2012a, Commission Staff Working Document, Elements for a Common Strategic Framework 2014 to 2020, the European Regional Development Fund the European Social Fund, the Cohesion Fund, the European Agricultural Fund for Rural Development and the European Maritime and Fisheries Fund, Brussels, 14.3.2012, SWD(2012) 61 final, Part I.

European Commission, 2012b, Commission Staff Working Document, Elements for a Common Strategic Framework 2014 to 2020, the European Regional Development Fund the European Social Fund, the Cohesion Fund, the European Agricultural Fund for Rural Development and the European Maritime and Fisheries Fund, ANNEXES, Brussels, 14.3.2012, SWD(2012) 61 final, Part II.

European Commission, 2013a, Recommendation for a COUNCIL RECOMMENDATION on Italy 2013 national reform programme and delivering a Council opinion on Italy's stability programme for 2012-2017, Brussels, 29.5.2013, COM(2013) 362 final.

European Commission, 2013b, The Compact for Growth and Jobs: one year on, Report to the European Council, 27-28 June 2013, in http://ec.europa.eu/europe2020.

European Court of Auditors, 2013, Special report No 5 2013, Are EU Cohesion Policy Funds well spent on roads?, Publications Office of the European Union, Luxembourg.

European Parliament, 2013, Resolution of 14 March 2013 on the Energy roadmap 2050, a future with energy, 2012/2103(INI), inwww.europarl.europa.eu.

Ezcurra R., Pascual P., 2008, Fiscal decentralization and regional disparities: evidence from several European Union countries, in "Environment and Planning A", 40(5), pp. 1185-1201.

Franco M., 2011, UE: sfide e opportunità della presidenza polacca, "EURASIA", Rivista di Studi Geopolitici, in "www.eurasia-rivista.org”, 24 Luglio 2011.

Hanzelewicz A., 2013, Polonia celebra 9 anni in UE, balzo del Pil del 46,3\%. Rapporto del Ministero degli esteri, la crisi aiuta a colmare il gap, in www.ansa.it, June 5, 2013, 4.47 p.m.

HU Presidency, 2011, Territorial Agenda 2020. Towards an Inclusive, Smart and Sustainable Europe of Diverse Regions, in "http://www.eu2011.hu".

Italian Trade Agency, 2012, POLONIA - Newsletter FONDI UE, n.21, ottobre - novembre 2012, in "http://www.ice.gov.it".

Jarczeswski W., 2010, Regional Observatories of Development Policy as a tool for monitoring the efficiency of the cohesion policy, in "Europa XXI", 2010, 21: 155-172.

Komornicki T. et al., 2011, The territorial state and perspectives of the European Union. 2011 update. Background document for the Territorial Agenda of the European Union 2020. Budapest: Vati, $2011-90$ pp.

Lukowski J., Zawadzki H., 2001, A concise history of Poland, Cambridge University Press, Cambridge. 
Lukowski J., Zawadzki H., 2009, Polonia. Il paese che rinasce, Beit, Trieste.

Mendez C., Wishlade F., Yuill D., 2006, Conditioning and Fine-Tuning Europeanization: Negotiating Regional policy Maps under the EU's Competition and Cohesion Policies, in "Journal of Common Market Studies", 44(3), pp. 581-605.

Ministero degli Affari Esteri, 2014, POLONIA, Rapporto Congiunto Ambasciate/ Consolati/ ENIT 2014, in "www.esteri.it/MAE/pdf_paesi/EUROPA/Polonia.pdf".

Ministero degli Affari Esteri, Ambasciata d'Italia, 2013, Polonia, in www.infomercatiesteri.it.

Ministero dell'Economia e delle Finanze, 2013, Documento di economia e finanza 2013, Sezione III Programma Nazionale di Riforme, deliberato dal Consiglio dei Ministri il 10 Aprile 2013.

Ministerstwo Rozwoju Regionalnego, 2013, Fundusze Europejskie 2014-2020, Założenia Umowy Partnerstwa przyjęte, Informacja prasowa, 15 stycznia 2013 r., in www.mrr.gov.pl.

Ministerstwo Rozwoju Regionalnego, 2013, Programowanie perspektywy finansowej 2014-2020, Założenia Umowy Partnerstwa, Przyjęte przez Radę Ministrów w dniu 15 stycznia 2013 roku, in www.mrr.gov.pl.

Ministerstwo Środowiska, 2013, Spotkanie Wysokiego Szczebla na rzecz klimatu i czystego powietrza w trakcie COP19/CMP9, in "www.mos.gov.pl", 2013-11-22.

Ministry of Regional Development, 2011, How to strengthen the territorial dimension of "Europe 2020" and EU Cohesion Policy, Background Report based on the Territorial Agenda 2020, Warsaw.

Ministry of Regional Development, 2012, National spatial development concept 2030, Summary of the Government Document approved by the Council of Ministers on 13 December 2011,Warsaw.

Ministry of Regional Development, 2013a, Place-based. Territorially sensitive and integrated approach, Warsaw.

Ministry of Regional Development, 2013b, Poland and its Funds, in www.funduszeeuropejskie. gov.pl.

Ministry of the Environment, 2013, Green Investment Scheme in Poland. GIS, by Ministry of the Environment in cooperation with National Fund for Environmental Protection and Water Management, Printed on paper with the PEFC certificate, in www.nfosigw.gov.pl.

Narodowy Fundusz Ochrony Środowiska i Gospodarki Wodnej, 2013, System zielonych inwestycji (GIS - Green Investment Scheme) Czesc 7) GAZELA, in www.nfosigw.gov. $\mathrm{pl} / \mathrm{en} /$ priority-programmes.

PAIIZ, 2012, Klimat Inwestycyjny w Polsce, Wyniki badania, Warszawa, październik 2012, in www. paiz.gov.pl.

Republic of Poland, 2012, National Development Strategy 2020, Active society, competitive economy, efficient State, Attachment to Resolution No 157 of the Council of Ministers of 25 September 2012, Warsaw.

Republic of Poland, 2013a, Convergence Program, 2013 UPDATE, Warsaw, April 2013.

Republic of Poland, 2013b, National Reform Programme, Europe 2020, 2013/2014 UPDATE, adopted by the Council of Ministers on 30 April 2013.

Rzeczpospolita Polska, Ministerstwo Spraw Zagranicznych, 2012, Przewodnictwo Polski w Radzie Unii Europejskiej. Raport końcowy z przygotowania i sprawowania prezydencji złożony przez Petnomocnika Rzqdu ds. Przygotowania Organów Administracji Rzq̨dowej i Sprawowania przez Rzeczpospolita Polska Przewodnictwa w Radzie Unii Europejskiej, na podstawie § 1. pkt 2. Rozporządzenia Rady Ministrów z dnia 15 lipca 2008 r. (Dz. U. nr 133, poz. 843 z późn. zm.), Raport przyjęty przez Radę Ministrów w dniu 17 kwietnia 2012 r. 
Szul R., 2102, Cohesion in the European Union: Economic, Political, Cultural Challenges, in "Europa XXI”, 22, 2012, Institute of Geography and Spatial Organization, Warsaw, pag. 13.

Tacconi M., 2013, L'Europa scopre lo shale gas, gli ambientalisti si mobilitano, in www.europaquotidiano.it/2013/10/27/leuropa-scopre-lo-shale-gas-gli-ambientalisti-si-mobilitano/\#, 27/10/2013. Tusk D., 2011, Polacy wierzq w projekt europejski, in www.consilium.europa.eu, 01/07/2011.

Wonka A., 2008, Decision-making dynamics in the European Commission: partisan, national or Sectoral, in "Journal of European Public Policy", 15(8), pp. 1145-1163.

Zamoyski A., 1994, The Polish Way: A Thousand-Year History of the Poles and Their Culture, Hippocrene Books, New York. 